\title{
Music as a Management Tool in Elementary Physical Education: A Qualitative Investigation
}

David C. Barney

Brigham Young University, david_barney@byu.edu

Keven A. Prusak

Brigham Young University, keven_prusak@byu.edu

Follow this and additional works at: https://scholarsarchive.byu.edu/facpub

Part of the Teacher Education and Professional Development Commons

\section{BYU ScholarsArchive Citation}

Barney, David C. and Prusak, Keven A., "Music as a Management Tool in Elementary Physical Education: A Qualitative Investigation" (2020). Faculty Publications. 4259.

https://scholarsarchive.byu.edu/facpub/4259

This Peer-Reviewed Article is brought to you for free and open access by BYU ScholarsArchive. It has been accepted for inclusion in Faculty Publications by an authorized administrator of BYU ScholarsArchive. For more information, please contact ellen_amatangelo@byu.edu. 


\section{Abstract}

Classroom management is an important aspect for a K-12 teacher in any content area.

3 The same applies in physical education (PE). In PE there are large spaces, students are moving,

4 and in many cases, equipment (basketballs, rackets, hula hoops, etc.) is involved. Thus, making

5 PE a unique challenge in regard to classroom management for PE teachers. One tool an

6 elementary PE teacher can use for classroom management is music. For this study, one school

7 administrator, 19 elementary-aged students and one PE teacher were interviewed to better

8 understand their perspectives of music as a management tool in elementary PE. Findings

9 indicate that students prefer music as a management tool, then the PE teacher using a whistle or

10 loud voice.

11 
Music as a Management Tool in Elementary PE

\section{Introduction}

For many K-12 teachers, the aspect of classroom management can be a major concern for

them. They may have a student or a number of students in their class (es) that make teaching

27 difficult for them and challenging for the other students to learn because of student misbehaviors

28 during class. This may also be true for those that teach physical education (PE). For PE teachers

29 regarding classroom management they have to take into account students being in a gymnasium,

30 out on a large playing field, or in a weight room. There is also equipment, such as basketballs,

31 rackets, weights, cones, jump ropes and a multitude of other equipment they have to manage so

32 that students don't hurt themselves or their classmates, and still learn as they are interacting with

33 the equipment. Then there is the element of students moving during games or activities. All

34 these examples and more are typical situations of classroom management in PE. Classroom

35 management has been defined as "organizing and controlling the affairs of a class. It refers to

36 how students are organized, started and stopped, grouped and arranged during class (Pangrazi \&

37 Beighle, 2013, p.98).

The literature has highlighted the importance of classroom management at all stages of a

39 PE teacher's career. This was illustrated when Physical Education Teacher Education (PETE) majors participated in a semester long elementary PE practicum (Barney \& Pleban, 2006). For

41 this study PETE majors were interviewed before (pre) they participated in their practicum and

42 interviewed again after (post) they completed their elementary PE practicum. In both the pre and

43 post interviews, classroom management was one of the main areas of concern in their teaching.

44 During the pre-practicum interviews many of the PETE majors were concerned with controlling

45 the students and keeping them on-task during class activities. In the post-practicum interviews

46 students felt that when students were on-task their classes were well managed. One student 
47 stated that at the end of her practicum her classroom management skills got better, but she still

48 worried about classroom management when she would be student teaching and eventually

49 teaching her own classes. These concerns regarding classroom management can be in the

50 forefront of many PE teachers mind.

51 With the importance classroom management can play in the PE context, PE teachers can

52 use specific methods to manage students. For example, PE teachers can use their whistle, can

53 split up students that are misbehaving, and use consistent start and stop signals to manage their

54 students (Pangrazi \& Beighle, 2013). Another method of classroom management a PE teacher

55 can implement is the use of music. The literature has primarily investigated the implementation

56 of music in PE to increase student activity (Brewer, Barney, Prusak, \& Pennington, 2016; Barney

57 \& Prusak, 2015 \& Deutsch \& Hetland, 2012) and student enjoyment in PE class (Barney, Pleban,

$58 \&$ Gishe, 2016). When conducting research with music in a physical activity (PA) context

59 Karageorghis, Jones, and Low (2006) created a conceptual framework. Four tenants make up

60 this framework, they are: a) rhythm response, b) musicality, c) cultural impact, and d)

61 association. Rhythm response refers to musical rhythm most notably tempo. Tempo refers to

62 the speed of music as measured in beats per minute (BPM). Musicality refers to the responses to

63 pitch-related elements such as harmony and melody. Cultural impact refers to the perverseness

64 of the music within society. Association refers to extramusical associations such as emotions

65 that a piece of music may evoke (Karageorghis, Jones, \& Low, 2006). Karageorghis, Terry and

66 Lane (1999) presented this conceptual model using these four factors to predict the effects of

67 asynchronous (i.e., absent of conscious synchronization between physical movement and

68 accompanying musical rhythm such as background music) motivational music in the context of

69 exercise and sport. 
Limited research has taken place regarding music as a management tool in PE. Yet, there

71 are studies that allude to music as a management tool. Harms and Ryan (2012) discussed using

72 music to enhance PE. The researchers observed four different elementary PE classes that used

73 music as a management tool on a regular basis. For the first two classes, the PE teacher used the

74 music to start and stop students throughout the lesson. No majors problems were observed in

75 these two classes. For the final two classes the researchers asked the PE teacher not to use music

76 as a management tool. The researchers noted that the PE teacher was hesitant when asked not to

77 use music in the lessons. For the last two lessons the researchers observed more off-task

78 behaviors, because no music was being played and many of the students were upset and angry

79 because no music was being played. The researchers suggest that music has positive effects

80 when used as a management tool in PE class. A second study investigated PE teachers'

81 perceptions of incorporating music in PE lessons and to evaluate the influence of music on the

82 classroom environment (Barney \& Pleban, 2018). For this study $26 \mathrm{~K}-12$ PE teachers were

83 surveyed. The survey consisted of open-ended questions requiring the PE teachers to explain

84 their responses to the survey questions. After analysis of the survey questions the following

85 themes were apparent. They felt they were putting students in a better position to learn the

86 content, that music helped provide a positive class climate, and music served as a motivational

87 tool. Yet, one of the main themes resulting from this study, was music played a part as a

88 management tool. Many of the PE teachers stated that music was a positive tool to assist with

89 classroom management. One of the PE teachers stated, "Instead of screaming and being loud to

90 get the class to focus, I stop the music to get attention. The sudden silence of no music gets their

91 attention quickly." Another PE teacher stated, "When music starts, students start activity. When

92 the music stops, students stop and look at me, or students put away equipment and rotate etc. 
93 Music make signals and students immediately recognize it." The results from both of these

94 studies dealing with music as a management tool, highlights music having a positive effect in

95 aiding PE teachers to manage students during class activities. The results from these studies are

96 positive, still there is a paucity of research dealing specifically with music as a management tool

97 in elementary PE class. Thus, the purpose of this study was to investigate music as a

98 management tool in elementary PE from the perspectives of a school administrator, the PE

99 teacher and elementary-aged PE students.

\section{Methods}

\section{Participants and Setting}

For this study, 19 elementary-aged students (7 males and 12 females), 1 female PE

103 teacher (9 years of teaching experience), and one male school administrator participated in the

104 study. The school that the participants came from was a public charter school located in the

105 Pacific. It has a student population of approximately 330 students (PK-6). Ethnic breakdown of

106 the student population was $61 \%$ Caucasian, $22 \%$ of two or more races, $9 \%$ Hispanic, $7 \%$

107 Hawaiian and 1\% Asian (Public School Review, 2020). University Institutional Review Board

108 (IRB) and the charter school gave approval to conduct the study. Parental consent as well were

109 obtained before the study proceeded.

\section{Procedures and Data Collection}

111 On the day of data collection, the researchers interviewed at the school, the school

112 administrator, the students and the PE teacher. The interviews took approximately 15 minutes in

113 length. The interviews were semi-structured and were audio-recorded. The interview questions

114 were different for the participants. Students that were interviewed were randomly selected. The 
115 interviews were designed to get the participants opinions and experiences relating to music as a

116 management tool in elementary PE.

117 Interview Data Analysis

118 For the analysis of the interviews, participant responses were correlated and reviewed to 119 generate preliminary coding categories, with framework analysis methodology for participant

120 responses, as outlined by Check and Schutt (2011). Framework analysis incorporated the stages

121 of 1) familiarization, 2) thematic, 3) identification, and 4) charting and interpretation (Rabiee, 122 2004).

\section{Music as a Management Tool in Elementary PE Themes}

124 Investigators read and re-read interview transcripts, identified themes and phrases. From

125 all survey responses, the most frequent management content themes were 1) Start and stop

126 signals, 2) Music is preferred rather than a whistle or a loud voice, and 3) Music stops, students 127 are given instructions (see Table 1).

\section{Results}

\section{Start and Stop Signals}

130 From the interview data, the use of music as a start and stop signal was a common and

131 constant theme. Mike (school administrator) stated:

132 "She uses it as a stop and start signal. A good management tool. Also, when Lori (PE 133 teacher) has a substitute, they follow her lesson and when they (the substitute) play music 134 the children do as they are supposed to do with the music playing. In large part because 135 of what they do every day in their class."

136 A number of students that were interviewed stated when the music starts, we "get moving" and

137 "when the music stops, we stop." Mary stated, "When the music starts you start to do what she 
138 tells you. For example, start skipping when the music starts. The class skips." Sally stated,

139 "When the music stops, we freeze. If we have equipment, we put it down as we freeze." And

140 Julie said, "I like the music to start us going. It is better than her blowing her whistle."

141 Music is preferred over a Whistle or Loud Voice

142 The second theme from the interviews dealt with the PE teacher not using a whistle or a

143 loud voice for management. Casey was asked if Miss L. uses a whistle to start and stop the class, 144 he said, "She used a whistle one time because the speaker wasn't working. The next day, the 145 speaker was working. I like the music better." Lilly made the same observation as Casey did 146 regarding the speaker not working. Lilly said, "I like the music so much more. The day the 147 speaker wasn't working, that wasn't good. I don't like the whistle." Beth stated that "I have 148 gotten used to hearing the music. When the music starts, I get going. And when the music stops, 149 I stop and face Miss L. When she doesn't use the music and uses a loud voice, I am surprised." 150 Lori was asked if music as a management tool has made her life better as she teaches PE. She 151 stated:

“I don't use a whistle. I hate whistles. When the music stops, the kids stop and so I don't have to speak as loud. It saves my voice. Because of this I have learned to give short and

155 Music Stops, Students are given Instructions

The final theme from the interviews was when the music stops, students are given

157 instruction. Emily said, "Miss L. tell us what she wants us to do when the music stops. She 158 doesn't want to waste time, and we move from one activity to another quicker." Steven said, 159 "When the music stops, Miss L. gives us instructions on what to do and what not to do. When 160 the music starts, we do what she told us to do." Paul said, "When she turns on the music, we 
161 have to be ready. And when she turns off the music we have to freeze. She wants us to listen to

162 what she says." John stated it a little differently, but with the same intent when he said, "The

163 music helps me focus on what Miss L asks us to do. So, I don't think of other things.”

164 Lori said:

165 "When I do jump rope for heart the parents see how I use music. That when the music stops, I give them their instructions for activity. I turn on the music and they do the activity. The parents see their children have been conditioned to the music and how they respond to it. The parents only say how much they like the kind of music I play. But, it shows the parents that when the music is off I will give their children instructions on what I want them to do." The purpose of this study was to investigate music as a management tool in elementary

173 PE from the perspectives of a school administrator, the PE teacher and elementary-aged PE

174 students. The results from the interviews from this study found music as a management tool in

175 elementary PE to be effective and preferred. Three themes came from interviews with a school 176 administrator, elementary-aged students and an elementary PE teacher. The themes were: 1)

177 music used as a start and stop signal, 2) music is preferred rather than a whistle or loud voice for 178 management, and 3) when the music stops, students are given instructions.

179 It was generally found that music is an effective tool for elementary PE teachers to use to 180 manage their students. Also, from the student perspective they like the music. When looking at 181 the themes closer, the first being the music as a start and stop signal helps set the environment 182 for the given class and lesson. For many students in elementary PE they have been in their 183 classrooms studying math, science, social studies or other content. The question can be asked, 
184 how have they been studying? They have been sitting at their desks. When students come to PE

185 class the PE teacher will start and stop the students two or three times. This gives the students a

186 chance to quickly warm-up the muscles, but it also gets the students to start and stop when the

187 music is played and when it stops (Pangrazi \& Beighle, 2013). This gets students thinking about

188 things that are physical in nature. Barney and Pleban (2018) interviewed K-12 PE teachers

189 dealing with music in their PE lessons. In one of the interviews a PE teacher stated, "When

190 music starts, students start activity. When music stops, students stop and look at me, or students

191 put away equipment and rotate etc. Music makes signals instant and students immediately

192 recognize it." Krystosek (2003) observed that students in PE classes without music were off task

193 more than students in PE classes with music playing. Thus, frequently reminding students to

194 stay on task. This only creates more unnecessary work for the PE teacher. From this study, one

195 student said, "When the music starts, I need to be moving, and when the music stops, I need to

196 stop and face Miss L.”

197 The second theme was music was preferred rather than a whistle or loud voice for

198 management, this can affect both the students and the teacher. For the students from this study

199 they preferred the music then hearing a whistle or the PE teachers loud voice. During an

200 interview with one of the students, they were asked if they preferred the music a whistle or a

201 loud voice. The student replied, "the music." The student was asked why. She stated, "The

202 music is much more fun, and the whistle isn't fun. If Miss L. uses a loud voice, sometimes it

203 sounds like she is yelling at us." Ryan (2009) studied the effects of a sound-field amplification

204 system on managerial time in a middle school PE setting. The results indicated that the field

205 amplification system reduced managerial time used in class, resulting in more instructional and

206 activity time during class. Yet, the researcher concluded that with the aid of a sound-field 
Music as a Management Tool in Elementary PE

207 amplification system it will help with PE teachers voice fatigue, which can be troubling for them

208 (Gotass \& Starr, 1993; Masuda, Ikeda, Manako, \& Komiyamas, 1993).

209 The final theme was when the music stops, students are given instructions from the PE

210 teacher. When analyzing the interview data from this study, Casey was asked why listening to

211 the music is important. He stated, "You can do what Miss L. asks you to do." Other student

212 comments regarding the importance of listening to the music was, "She gives instructions", "We

213 do what Miss L. wants us to do", and "She tells us to do a task when the music starts." Harms

214 and Ryan (2012) found that when the music stops, students will stop, look and listen to the

215 teacher regarding their activity. When Barney and Pleban (2018) interviewed K-12 PE teachers,

216 one of them said:

217 "If implemented correctly, music can be used to manage the classroom by giving the 218 students cues on what to do when they hear the music stop or when they hear the music

219 start. If not implemented correctly, many classrooms can turn into a zone of poor 220 management."

221 The conditioning of students in PE class to listen and then follow instructions may seem over

222 simplified. Yet, this simple skill of listening to instructions will serve the student well in their

223 education and then throughout their life in general.

\section{Conclusions}

225 This study investigated music as a management tool in PE class. Because of the paucity 226 of research dealing with the topic, this study only helps strengthen and add to the literature.

227 Results from this study appear to coincide with the limited literature in regard to music as a 228 management tool in PE class. Pangrazi and Beighle (2013) stated that music as a management 229 tool is effective with elementary-aged students. The authors continued by saying, "managing 
230 student behavior is not easy. A class of children is a group of individuals, each requiring unique

231 treatment and understanding" (p.98). With the challenge of working with a variety of

232 personalities, some more challenging than others, music can be used in teaching simple, yet

233 important skills, that when learned and followed will benefit the student and have the potential to

234 affect their learning in PE class. Barney and Leavitt (2019) feel that music helps create a

235 positive environment, and when using music in the capacity of management there is the 236 possibility of continuing the positive environment in the PE class.

\section{Study Implications}

238 The implications of this study have the possibility of benefitting current elementary PE

239 teachers, PETE majors and PETE faculty. As illustrated from this study elementary PE teachers

240 can successfully implement music as a management tool. During the interview with Lori she

241 stated, "It is pretty instantaneous with music when teaching students management. It is a matter

242 of being consistent and doing it every day." For PETE majors, they need to understand and

243 experience that music can be an effective management tool and should be implemented during

244 the elementary PE practicum and student teaching experience. For PETE faculty they can

245 introduce music as a management tool in their methods of teaching elementary PE. Then when

246 the PETE majors go out to elementary school and teach, the PETE faculty can encourage and

247 help them to see how music can benefit and strengthen their management as they teach. When

248 interviewing Lori, she mentioned that in her undergraduate program she was introduced to the

249 concept of music as a management tool by one of her professors. From there she used music in

250 her practicums, student teaching and now in her own PE classes. For the PETE faculty the use of

251 music as a management tool can be discussed in class, modeled to the students before they

252 participate in their elementary PE practicum, and go to the elementary school during the 
253 practicum to observe the PETE major teaching with music. Then sitting down with the PETE

254 major to discuss their classroom management experiences with music.

256 A limitation of this study is the inability to generalize these findings to other elementary

257 schools in the other parts of the United States. Because of the use of a sample of convenience

258 from one elementary school PE program, further generalization of this data must be approached

259 with caution. Further study should be done using multiple elementary school PE programs at

260 different schools and in different regions of the United States to explore the reproducibility of the

261 process and findings.

262

263

264

265

266

267

268

269

270

271

272

273

274

275 
Music as a Management Tool in Elementary PE

\section{References}

277 Barney, D., \& Leavitt, T. (2019). A qualitative investigation of PE teachers' perceptions of introductory/warm-up activities in PE. The Physical Educator, 76, (1), 86-96.

279 Barney, D., \& Pleban, F. (2018). An examination of physical education teachers' perceptions of utilizing contemporary music in the classroom environment: A qualitative approach. The Physical Educator, 75, (2), 195-209.

Barney, D., \& Pleban, F. (2006). Pre-service physical education teacher's perceptions of teaching before and after a semester long practicum experience. The Physical Educator, 63, (1), 46-52.

Barney, D., Pleban, F., \& Gishe, J. (2016). The effects of music in enhancing the elementary physical education environment. International Journal of Physical Education, 23-32.

287 Barney, D., \& Prusak, K.A. (2015). The effects of music on physical activity rates on elementary physical education students. The Physical Educator, 72, (2), 236-244.

289 Brewer, L., Barney, D., Prusak, K., \& Pennington, T. (2016). The effects of music on physical activity rates of junior high school physical education students. The Physical Educator, 73, (4), 689-703.

292 Check, J., \& Schutt, R. (2011). Research methods in education. Thousands Oak, CA: Sage.

293 Deutsch, J., \& Hetland, K. (2012). The impact of music on pacer test performance, enjoyment and workload. Asian Journal of Physical Education and Health, 18, (1), 6-14.

295 Gotass, C., \& Starr, C.D. (1993). Vocal fatigue among teachers. Folia Phoniatrica et Logopaedica, 45, (3), 120.

297 Harms, J., \& Ryan, S. (2012). Using music to enhance physical education. Journal of Physical 298 Education, Recreation and Dance, 83, (3), 11-12, 55. 
Music as a Management Tool in Elementary PE

299 Karageorghis, C.I., Jones, L., \& Low, D.C. (2006). Relationship between exercise heart rate and 300 music tempo preference. Research Quarterly for Exercise and Sport, 77, 240-250.

301 Karageorghis, C.I., Terry, P.C., \& Lane, A.M. (1999). Development and initial validation of an 302 instrument to assess the motivational qualities of music in exercise and sport: The brunel 303 music rating inventory. Journal of Sports Sciences, 17, 713-724.

304 Krystosek, K. (2003). To have music or not to have music in elementary physical education: That is the question. Unpublished manuscript.

Masuda, T., Ikeda, Y., Manako, H., \& Komiyames, S. (1993). Analysis of vocal abuse: Fluctuations in phonation time and intensity in four groups of speakers. Acta Otolaryngol, 113, 547-552.

309 Pangrazi, R.P., \& Beighle, A. (2013). Dynamic physical education for elementary school children (17 $7^{\text {th }}$ ed.). Boston, MA: Pearson.

311 Public School Review. (2020). Retrieved April, 15, 2020, from http://publicschoolreview.com.

312 Rabiee, F. (2004). Focus-group interview and data analysis. Proceedings of the Nutrition Society, 63, 655-660.

314 Ryan, S. (2009). The effects of a sound-field amplification system on management time in middle school physical education setting. Journal of Language, Speech, and Hearing

$316 \quad$ Services in Schools, 40, 131-137. 
Music as a Management Tool in Elementary PE

\section{Table 1}

323 Interview Themes Regarding Music as a Management Tool in Elementary PE

Comments

The PE Teacher Doesn't use a

Whistle or a Loud Voice

\section{Given Instructions}

"When the music starts, we get moving, and when stops we stop"

"When the music stops are eyes are on Miss L."

"I like the music so much more. The day the speaker wasn't working wasn't good."

"I don't use a whistle. I hate whistles."

"Miss L. tells us what to do when the music stops. She doesn't what to waste time."

"When the music stops, Miss L. gives us instructions on what to do and what not to do." 